\title{
Visual Materials and their Impact on Students' Achievement during Virtual Learning
}

\author{
Baan Jafar Sadiq ${ }^{1}$ \\ \{ban@copew.uobaghdad.edu.iq $\left.{ }^{1}\right\}$
}

College of Education for Women/ Baghdad University ${ }^{1}$

\begin{abstract}
Visual materials are tools that could help the teachers in class to manufacture the necessary knowledge for effective and delightful teaching. The current research has used visual materials and investigated experimentally their impact on students' achievement in teaching English as a Foreign Language during the virtual learning of pandemic of Covid-19. The sample of the research is 64 students at the College of Physical Education and Science Sport for Women/Baghdad University which they are divided into two groups, the experimental is taught according to the visual materials (Sadiq, 2019) while the second one is taught by using the traditional textbook only (Abdul- Razzaq\& AlMufti, 1987). After three months, the results of the pre and post-tests are analyzed statistically. And the results are revealed that there is a significant difference for the visual materials group. Therefore, it is indicated using visual materials in English foreign teaching is effective as a tool for presenting printing materials.
\end{abstract}

Keywords: Visual materials, Students' achievement, EFL, ESP, Virtual learning.

\section{Introduction}

\subsection{The Problem and Its Significance}

Visual materials are utilized in this research as a tool for teaching EFL which might help English lecturers to present knowledge with variegated, pleased and effective in school to create the teaching go easily and smoothly to all or any students furthermore teachers. This research has answered that visual materials have an impact on students' achievement. Because a variety of studies show that the utilization of visual materials is regarded as a useful means to motivate learners, arouse their interest, and expose them to life situations. Aisyah, Atmaja1, \& Gina, Sonia [1] have used flashcards in teaching vocabulary while the present research is vocabulary and dictation. Students are tormented by many sports and their meaning in Arabic so this research is exposed to the scholars for another textbook.

Nowadays, English teachers are concerned about preparing students for world situations in the classes. Therefore, like other teachers around the world, teachers have to implement active teaching materials, to assist the students to learn English better [2]. 


\subsection{Aim of the Research}

Exploring experimentally the Visual Materials and their impact on student's achievement is the aim of the research.

\subsection{Hypothesis of the Research}

It is assumed that there are not any statistically significant differences between the experimental group who taught English by visual materials [3] and the control group who taught English by the textbook only [4].

\subsection{Limits of the Research}

The research is limited for the following:

Using the visual materials in English foreign language teaching.

Students at College of Physical Education and Sciences Sport for Women.

The educational year 2020-2021.

\subsection{Definition of Basic Terms}

Visual Materials:

Richards \&Schmidt [5] define visual materials as "the use of materials that weren't originally developed for pedagogical purposes, like the utilization of magazines, newspapers, and advertisements. Such materials are often thought to contain more realistic and natural samples of language use than those found in textbooks other specially developed teaching materials" According to Herod [6] states that visual materials and activities are designed to imitate important world situations.

Jacobson et al [7] see visual materials as printed materials, which are utilized in classrooms in the same way they might be employed in the world.

\section{Method of the Research}

\subsection{The Experimental Design}

An experiment design with two groups pre- post-tests design has been implemented to achieve the aim of the research as well as to identify whether visual materials are efficient in teaching English or not. Thus, The control group has taught according to the current textbook [4], while the experimental group has taught by using the visual materials using [3] as shown in Table 1.

Table 1. Experimental Design.

\begin{tabular}{|l|l|l|l|}
\hline Experimental group & Pre-test & $\begin{array}{l}\text { Independent variable } \\
\text { Visual Materials (Sadiq, 2019) }\end{array}$ & Post-test \\
\hline
\end{tabular}




\begin{tabular}{|l|l|l|l|}
\hline Control group & Pretest & $\begin{array}{l}\text { Textbook (Abdul- Razzaq\& Al-Mufti, } \\
1987)\end{array}$ & Post-test \\
\hline
\end{tabular}

\subsection{Population and Sample Selection}

The first-year stage at the College of education and Sciences Sport for Women at the educational year 2020-2021 is randomly chosen to represent the sample of the research. The full population of the research is 121 while the number of the sample is 64 divided into 31 as an experimental group, and 33 as the control group, thus it means the sample of the research is representative one as shown in Table 2.

Table 2. Number of Subjects before and after Excluding the Repeaters.

\begin{tabular}{|l|c|l|l|}
\hline Group & Section & No. of Subject before excluding & No. of Subject After Excluding \\
\hline Experimental group & C & 34 & 31 \\
\hline Control group & A & 35 & 33 \\
\hline Total & & 69 & 64 \\
\hline
\end{tabular}

\subsection{Equalization}

Equalization of the sample in age and pre-test is made to ensure accuracy of the results of the research, as shown in Table 3 for statistics of equalization of the two groups in age and Table 4 for t-test statistics of equalization between the two groups in pre-test variables.

Table 3. The T-test Statistics of Equalization between the two Groups in Age.

\begin{tabular}{|c|c|c|c|c|c|c|c|}
\hline & \multirow{2}{*}{$\begin{array}{l}\text { No. } \\
\text { Students }\end{array}$} & \multirow[t]{2}{*}{ X Mean } & \multirow[t]{2}{*}{ S.D } & \multirow{2}{*}{$\begin{array}{l}\text { Degree of } \\
\text { Freedom }\end{array}$} & \multicolumn{2}{|l|}{ T Value } \\
\hline \multicolumn{2}{|l|}{ Group } & & & & & $\begin{array}{l}\text { Calculate } \\
\text { d Value }\end{array}$ & $\begin{array}{l}\mathrm{t}- \\
\text { distribution }\end{array}$ \\
\hline \multirow[t]{2}{*}{ Pre-test } & E. & 31 & 20.36 & 1.410 & \multirow[b]{2}{*}{62} & \multirow[b]{2}{*}{0.425} & \multirow[b]{2}{*}{1.98} \\
\hline & $\mathrm{C}$ & 33 & 20.19 & 1.364 & & & \\
\hline
\end{tabular}

Table 4. The T-test Statistics of Equalization between the Two Groups in Pre Test.

\begin{tabular}{|c|c|c|c|c|c|c|c|}
\hline \multirow{2}{*}{\multicolumn{2}{|c|}{ Group }} & \multirow{2}{*}{$\begin{array}{l}\text { No. } \\
\text { Students }\end{array}$} & \multirow[t]{2}{*}{ X Mean } & \multirow[t]{2}{*}{ S.D } & \multirow{2}{*}{$\begin{array}{l}\text { Degree of } \\
\text { Freedom }\end{array}$} & \multicolumn{2}{|l|}{ T Value } \\
\hline & & & & & & $\begin{array}{l}\text { Calculate } \\
\mathrm{d} \text { Value }\end{array}$ & $\begin{array}{l}\mathrm{t}- \\
\text { distribution }\end{array}$ \\
\hline \multirow[t]{2}{*}{ Pre-test } & E. & 31 & 6.483 & 1.411 & \multirow[b]{2}{*}{62} & \multirow[t]{2}{*}{1.208} & \multirow[b]{2}{*}{1.98} \\
\hline & C & 33 & 6.969 & 1.793 & & & \\
\hline
\end{tabular}

The mean score of the two groups in age is 20.36 for the experimental group while 20.19 for the score of the control group. The mean scores of the two groups in the pre-test are compared; the mean scores of the experimental group are 6.483, while the mean scores of the control group are 6.969 which indicates that there is no significant difference between the two groups in age and pretest. 


\subsection{Instructional Material}

The teacher herself has taught both groups with two different textbooks [4] "A Course in English for Colleges of Physical Education" (see Appendix 4) for the control group, while [3] (See Appendix 3) for the experimental group.

The important thing in teaching education is introducing the scholars to sports and games in English. Therefore, the traditional textbook introduces games as a listing of words and their translation in Arabic, the scholars suffer from memorizing long lists of words and their spelling. Thus, they forget the spelling and also the game itself. So, to resolve this problem the scholars have handed printed pictures materials regarding the games. the coed has a good basis of data about the sports within the world, classify these sports as water games, strength games, target games, animals games, racket games, gymnastics games, cycling games, and so on). similarly, scholars have brought more pictures and charts to introduce games. The whole period of the experiment has lasted two months (first course) (1/12/2020-1/2/2021).

\subsection{The Written Test}

The examiners are exposed to post-test including three questions as is shown in appendix (2) which it is tested the students' abilities in writing, spelling, and general information about games and sports also, it is contained recognizing the sport, complete the missing letters of the games and re-ordering the letters of the games and the test is scored out of twenty-five marks. The test is exposed to jury members for insurers its validity as well for reliability Person formula has been used to find out the correlation coefficient; the results show that the correlation coefficient of reliability is $(+.872)$ and this is considered a high stable correlation [8].

\section{Results}

To clarify whether there is a significant difference between pre and post-tests of students' achievement of a sample, the results have been analyzed. (Appendix 1)

\subsection{Assessment of the Post-Tests}

The mean score of the experimental group is 14.774 , while the mean score of the control group is 8.393 which reveals that there is a statistically significant difference at the level of 0.05 and degree 62 . Accordingly, the hypothesis is excluded. This could be explained by using the visual materials in teaching the experimental group. Thus, the visual materials are more efficient in teaching English than the current textbook as shown in Table 5.

Table 5. T-test of the two groups in post-test.

\begin{tabular}{|c|c|c|c|c|c|c|c|}
\hline \multicolumn{2}{|l|}{ Group } & \multirow{2}{*}{$\begin{array}{c}\text { No. } \\
\text { Students }\end{array}$} & \multirow[t]{2}{*}{ X Mean } & \multirow[t]{2}{*}{ S.D } & \multirow{2}{*}{$\begin{array}{l}\text { Degree of } \\
\text { Freedom }\end{array}$} & \multicolumn{2}{|c|}{ T Value } \\
\hline & & & & & & $\begin{array}{l}\text { Calculate } \\
\text { d Value }\end{array}$ & $\begin{array}{l}\mathrm{t}- \\
\text { distribution }\end{array}$ \\
\hline Post-test & $\mathrm{E}$ & 31 & 14.774 & 3.461 & 62 & 7.601 & 1.98 \\
\hline
\end{tabular}




\begin{tabular}{|l|l|l|l|l|l|l|l|}
\hline & $\mathrm{C}$ & 33 & 8.393 & 3.239 & & & \\
\hline
\end{tabular}

\subsection{Discussion of the Results}

The high scores of the experimental group could be explained to the following points:

- Visual materials are pleasant rather than a printed textbook.

- the students are motivated when they are used visual materials.

- The visual materials are accurate than the current textbook.

- The visual materials are recalled than the printed ones.

The research is going in parallel with [1] that flashcards are effective in teaching vocabulary.

\section{Conclusion and Recommendation}

The results which are revealed show the effectiveness of the proposed textbook therefore, Colleges of Physical Education and Sciences Sport are recommended to use visual materials in teaching English rather than printed textbooks, especially with virtual learning.

\section{References}

[1] Aisyah, Atmaja1, \& Gina, Sonia . Using Flash Cards To Improve Students' Vocabulary: PROJECT (Professional Journal of English Education) Volume 3, No. 2, March 2020.

[2] Martinez, A.G. (2002). Visual materials. An overview. Free resources for teachers and students of English, Karen's Linguistics Issues, 1-7.

[3] Sadiq, Baan (2019) Sport: Write \& Learn. Baghdad: Waghdy Publishing. ISBN: 978-99229260-0-1.

[4] Abdul- Razzaq\& Al-Mufti (1987) A Course in English for Students in the Colleges of Physical Education. Baghdad: University of Baghdad Press.

[5] Richards, J. \&Schmidt, R (2002) Dictionary of Language Teaching \& Applied Linguistics. 3rd ED. London: Pearson Education.

[6] Herod, L. (2002). Adult learning from theory to practice. Heinle and Heinle Publishers. Heinemann.

[7] Jacobson, E., Degener, S., \& Purcell-Gates, V., (2003). Creating visual materials and activities for the adult literacy classroom: A handbook for practitioners. USA: NCSALL.

[8] Valette, R.( 1977) Modern Language Tests. 2nd Ed. New York: HarcoutBrance. 